Hydrol. Earth Syst. Sci. Discuss., 6, 1769-1795, 2009 www.hydrol-earth-syst-sci-discuss.net/6/1769/2009/ (C) Author(s) 2009. This work is distributed under the Creative Commons Attribution 3.0 License.
Hydrology and Earth System Sciences Discussions

Papers published in Hydrology and Earth System Sciences Discussions are under open-access review for the journal Hydrology and Earth System Sciences

\title{
The artificial water catchment "Chicken Creek" as an observatory for critical zone processes and structures
}

\section{W. Gerwin ${ }^{1}$, T. Raab ${ }^{2}$, D. Biemelt ${ }^{3}$, O. Bens ${ }^{4}$, and R. F. Hüttl ${ }^{4}$}

${ }^{1}$ Brandenburg University of Technology Cottbus, Research Center Landscape Development and Mining Landscapes, Cottbus, Germany

${ }^{2}$ Brandenburg University of Technology Cottbus, Chair of Soil Protection and Recultivation, Cottbus, Germany

${ }^{3}$ Brandenburg University of Technology Cottbus, Chair of Hydrology and Water Resources Management, Cottbus, Germany

${ }^{4}$ German Research Centre for Geosciences GFZ, Potsdam, Germany

Received: 30 January 2009 - Accepted: 2 February 2009 - Published: 5 March 2009

Correspondence to: W. Gerwin (werner.gerwin @tu-cottbus.de)

Published by Copernicus Publications on behalf of the European Geosciences Union.

\section{HESSD}

$6,1769-1795,2009$

The artificial water catchment "Chicken

Creek"

W. Gerwin et al.

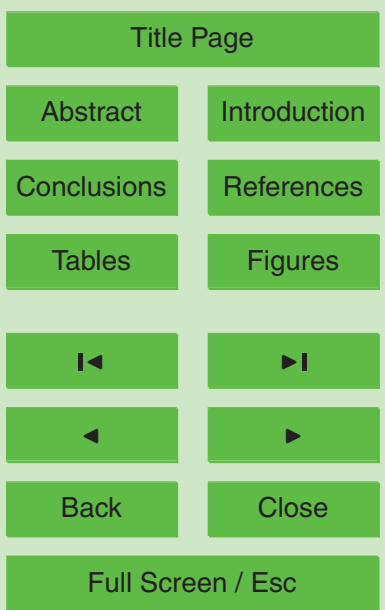

Printer-friendly Version

Interactive Discussion 


\section{Abstract}

In order to better understand the processes of the "Critical Zone" investigations are mainly carried out in watersheds as they represent parts of the landscape having more or less defined outlines. However, natural watersheds must, in some cases, be charac5 terized as "black boxes" with respect to e.g. structures in the underground or catchment boundaries which are generally unknown and need great efforts to be explored. Artificially created watersheds might, thus, be an appropriate alternative as boundaries and inner structures can be planned and defined in advance. This paper presents a recently launched project dealing with the initial phase of ecosystem development with 10 a man-made catchment as central research site. The research site has an area of 6 ha and can be regarded as one of the largest artificial watersheds developed for scientific purposes worldwide. It was completed in 2005 and left for an unrestricted ecosystem succession. This paper introduces the creation and main properties of this site as well as first results of an ongoing monitoring program.

\section{Introduction}

The "Critical Zone" concept is a new approach for a holistic view on the Earth's surface. It includes geological layers, soil horizons, vegetation cover, groundwater as well as surface water and also the air in the near surface part of the atmosphere and in the soil (Chorover et al., 2007). The Critical Zone is therefore defined as the interface between biotic and abiotic structures and can be regarded as the basis of life on Earth. This upper part of the Earth crust is characterized by a huge complexity of different biotic and abiotic processes. Recently, first Critical Zone Observatories (CZO) were established in order to gain a broader understanding of the behaviour of this crucial part of the planet (Wilding and Lin, 2006; Anderson et al., 2008).

25 Ecological studies with often more or less disciplinary approaches have been carried out frequently in the past decades. Additionally, a number of interdisciplinary
HESSD

6, 1769-1795, 2009

The artificial water catchment "Chicken Creek"

W. Gerwin et al.

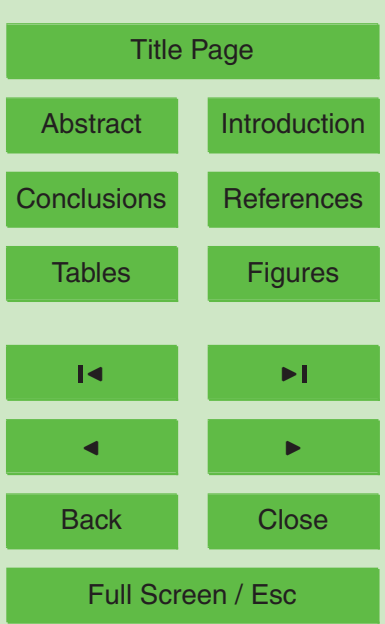

Printer-friendly Version

Interactive Discussion 
studies on terrestrial sites have been concentrating on forest ecosystems, others on agricultural landscapes, or even on landscapes with different and complex types of land-use (e.g. Ellenberg et al., 1986; Campbell et al., 2007; Fränzle et al., 2008). Based on these comprehensive approaches, networks such as the International Long5 Term Ecological Research (ILTER) Network have been established with more than 20 countries contributing a large number of monitoring sites (Waide et al., 1998). Recently, several additional networks have also emerged in addition to the Critical Zone Exploration Network (CZEN). In Germany, these include for example the Biodiversity Exploratories funded by the Deutsche Forschungsgemeinschaft (DFG) and the Terres10 trial Environmental Observatoria (TERENO) implemented by the Helmholtz Association (http://www.biodiversity-exploratories.de, www.tereno.net).

Most of these research activities are based on watersheds as natural units with more or less well defined boundaries. In principle, the use of watersheds as a fundamental landscape unit allows for the calculation of water and matter balancing (e.g. Gburek and Folmar, 1999; Lemonds and McGray, 2007). However, in many cases watersheds cannot be regarded as clearly defined sub-units of a landscape but have to be considered at least in part as "black boxes". Often fundamental information regarding the inner structures or even the surface and sub-surface boundaries are missing (Kendall et al., 2001; Sivapalan et al., 2003). Furthermore, research on watersheds is mainly conducted in "adult" or at least non initial ecosystems which are characterized by highly complex structures and processes. Thus, to date, important internal links and interactions within the Critical Zone are not very well understood. In addition, only limited knowledge exists on the initial phase of ecosystem development although early events, processes and structures influence the later development and also "small differences early in the process can ramify over time" (Walker and del Moral, 2003, p. 329).

A recently launched German-Swiss Collaborative Research Centre (SFB/TRR 38) aims to highlight the initial development phase of an ecosystem and the interactions within the Critical Zone. The project is using an artificial water catchment as the research object. Up to now, only few artificial catchments exist e.g. in China (Gu and
HESSD

6, 1769-1795, 2009

The artificial water catchment "Chicken Creek"

W. Gerwin et al.

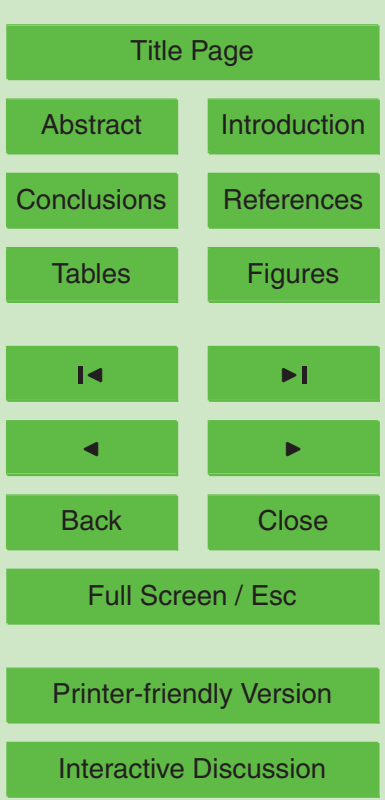


Freer, 1995; Gu, 1988), Canada (Barbour et al., 2004) and Spain (Nicolau, 2002) (cf. Table 1). Even if this overview of different types of artificial catchments is certainly not complete it is obvious that many of the existing sites are used for more or less disciplinary research. In addition, as the construction of an artificial catchment needs huge efforts both with respect to the construction work itself and the financial aspects most man-made watersheds are restricted to small dimensions which limit the transfer of results to real landscape units. This paper introduces a new research attempt using an artificial catchment as an observatory for investigating interactions between different abiotic and biotic ecosystem compartments and that follows accordingly the interdisci10 plinary concept of the Critical Zone approach. The hypotheses of the project as well as some first insights into the concept of research sites are presented here.

\section{Collaborative Research Centre}

The DFG funded Transregional Collaborative Research Centre (SFB/TRR 38) "Structures and processes of the initial ecosystem development phase in an artificial water 15 catchment" (http://www.tu-cottbus.de/sfb_trr/) started in 2007 and aims to investigate the relationships between abiotic and biotic parts of a complete ecosystem starting from "point zero" of its development. The main hypothesis of the project is that initial structures not only define and shape the development of an ecosystem but also influence the system during its later stages. The following central objectives of this project are (1) to reveal which abiotic and biotic structures and processes control the initial phase of the ecosystem development; (2) to elucidate which interactions exist between processes and both abiotic and biotic structures in the initial phase; (3) to investigate differences between processes and structures of initial systems compared with mature ecosystems; (4) to derive and define different stages of the ecosystem development; and (5) to find parameters that allow the transfer of results to other ecosystems in the initial stage.

This collaborative approach places special emphasis on the spatial and temporal dy-

\section{HESSD}

6, 1769-1795, 2009

The artificial water catchment "Chicken Creek"

W. Gerwin et al.

Title Page

Abstract

Introduction

Conclusions

Tables

References

Figures

14

$\rightarrow$

4

Back

Close

Full Screen / Esc

Printer-friendly Version

Interactive Discussion 
namics of both structures and accompanying processes and their interactions. Structures can be e.g. patterns of vegetations, soil compartments as well as hydrological structures such as flow paths or the developing groundwater body itself (Fig. 1). Abiotic compartments of natural systems can be characterized by the main factors

5 "substrate/soil", "water" and "climate". The characteristics of these structures and processes can be interpreted as indicators of the state of the whole system. In the beginning, particularly abiotic, i.e. physical structures control the first level of development of an ecosystem (Fig. 2). Especially hydrological factors dominate the dynamics of the system. Biotic factors appear later accompanied by organic matter accumulation 10 which influences the further development. Therefore, it is hypothesised that three main stages or sub-periods of the ecosystem development can roughly be distinguished: (1) a more or less abiotic Geo-System; (2) followed by a Hydro-Geo-System; and (3) the Bio-Hydro-Geo-System which represents the complete ecosystem as part of the Critical Zone (Fig. 2). Within the first two stages, physical and chemical weathering of 15 the accumulation of organic substance in and above the surface are crucial for the soil development and for the colonization of the site. The developing vegetation patterns are closely correlated with biomass accumulation above and below the surface and function as the basis for food webs and the establishment of consumer and destruent 20 communities.

It is intended to bring all spatial information on structures and processes development together in a central integrating structure and process model that will be developed within the project. This model will be the most important tool to differentiate and to elucidate different development phases. The objective of this model is the visualization of temporal and spatial dynamics of structures and processes and the interpretation of structure-process-interactions. The necessary input derives from a comprehensive long-term monitoring programme which is carried out with a high temporal and spatial resolution.

\section{HESSD}

6, 1769-1795, 2009

The artificial water catchment "Chicken Creek"

W. Gerwin et al.

Title Page

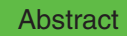

Introduction

Conclusions

Tables

References

Figures

14

4

Back

Close

Full Screen / Esc

Printer-friendly Version

Interactive Discussion 


\section{Concept of research sites}

The artificially created water catchment "Chicken Creek" ("Hühnerwasser") is the fundamental basis of these investigations and the central and joint research object of the Collaborative Research Centre. It has been constructed in an open cast mine in 5 Lusatia (Germany) based on experiences obtained with another artificial catchment ("Neuer Lugteich") built several years previously (Fig. 3). Additional research sites have been established and chosen to complete the set of investigation sites. Experimental plots are situated close-by the watershed and exhibit comparable initial site conditions. These plots allow specific manipulations, destructive sampling strategies 10 and replications of experimental approaches. Furthermore, the concept comprises specific reference sites. On the basis of these sites the occurrence and frequency of typical structures and processes in the initial development phase can be validated under different site conditions.

\subsection{Artificial catchment}

15 As the central investigation site of the project, the Brandenburg University of Technology at Cottbus planned an artificial catchment area for scientific use together with the mining company Vattenfall Europe Mining AG. The post-mining landscapes of the Lusatian lignite mining district (Eastern Germany) offered the necessary technical prerequisites and land for the construction of an artificial water catchment at the landscape

scale. The construction of the site was realized between 2004 and 2005 in the opencast mine Welzow-South ( $150 \mathrm{~km}$ south from Berlin). It has been named "Chicken Creek" ("Hühnerwasser") after the small stream existing here before mining started. The site has been constructed as the headwaters for the "Hühnerwasser", which will be restored later on. The catchment covers an area of approximately 6 ha (Fig. 4) and has a storage volume (aquifer) of $117500 \mathrm{~m}^{3}$ (Kendzia et al., 2008).

Prior to this, the mining company itself gained first experiences within another smaller catchment area close-by ("Neuer Lugteich") which was created in 2001. This first
HESSD

$6,1769-1795,2009$

The artificial water catchment "Chicken Creek"

W. Gerwin et al.

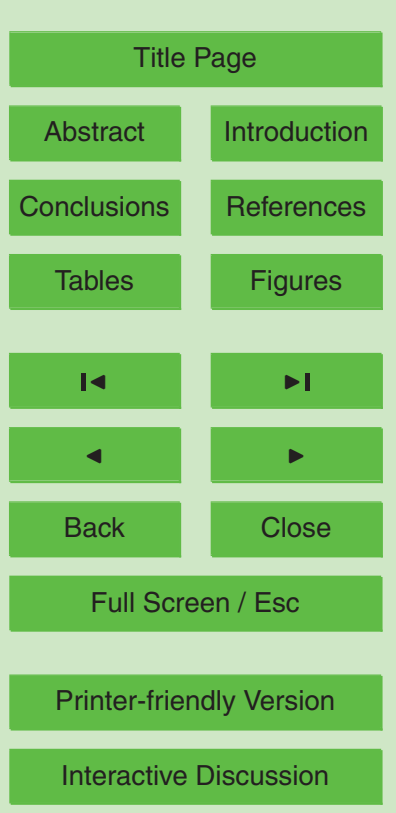


model catchment was specifically designed for scientific studies of different reclamation measures. Hereby aspects of the water balance in the catchment area, soil formation and carbon storage in addition to the development of surface structures following from erosion and sedimentation played a key role (Haubrock et al., 2004, 2008; Kuhnert et 5 al., 2005; Lemmnitz et al., 2008).

The study area "Neuer Lugteich" comprises a catchment of approximately 5.0 hectare in size, with 4.3 ha catchment area and 0.7 ha surface water (Kendzia et al., 2008). To deliver a basis for balancing and modelling with respect to the development of the water and element balance, this first artificially created catchment avails 10 an aquiclude made of clay deposit. The aquiclude (clay layer, 1 to $2 \mathrm{~m}$ thickness, partly compacted, permeability (kf) approx. $10^{-9} \mathrm{~m} \mathrm{~s}^{-1}$ ) is located at a depth of about $2 \mathrm{~m}$ below the surface. Above this layer a storage layer (1 to $2 \mathrm{~m}$ sand fill, permeability ( $\mathrm{kf}$ ) approx. $10^{-4} \mathrm{~m} \mathrm{~s}^{-1}$ ) has been dumped. These overburden substrates were deposited on the clay layer without further amelioration measures (e.g. liming, fertilizing). Already

since 2002, a permanent water level has been observed in the "Neuer Lugteich" pond, fed by tributaries from the designed catchment area. A shallow aquifer exists on top of the clay layer, with groundwater levels located about $0.5-1.5 \mathrm{~m}$ below the terrain surface (Kendzia et al., 2008; Lemmnitz et al., 2008). Thus it was proven that a functional groundwater aquiclude can be constructed on a landscape scale.

Compared with the later constructed "Chicken Creek" catchment, a number of differences have to be stated with respect to the selection of substrates. In contrast to the "Chicken Creek" catchment parts of the sandy substrate at the "Neuer Lugteich" stem from Tertiary layers containing small amounts of lignite and xylite fragments in order to investigate specific reclamation issues. This type of substrate can be characterized by a highly acidic soil solution, a higher organic carbon content of $0.35 \%$ (Quaternary substrate $0.15 \%)$, and a higher electric conductivity $(79-2940 \mu S$, mean $983 \mu S)$ than the Quaternary sands (23-342 $\mu S$, mean $65 \mu S)$.

The previous studies at the "Neuer Lugteich" catchment formed a significant basis for the construction of the neighbouring, and since 2005 established catchment area

\section{HESSD}

6, 1769-1795, 2009

The artificial water catchment "Chicken Creek"

W. Gerwin et al.

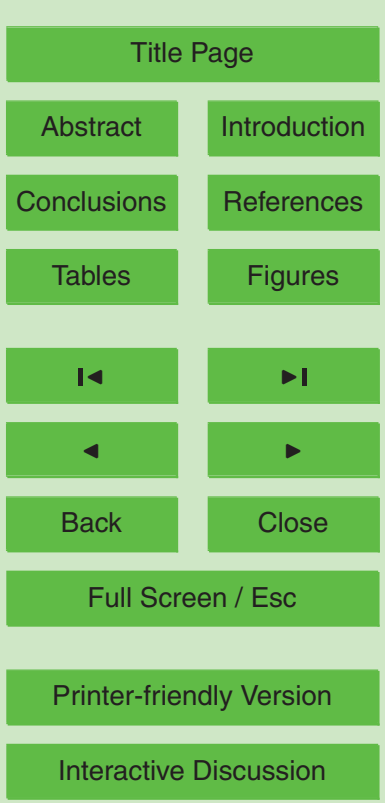


"Chicken Creek". As with the first artificial water catchment, the "Chicken Creek" catchment was constructed by means of large dumping devices from the lignite open-cast mine. On top of the base layer above the surface of the initial deposits, a clay layer of 2$3 \mathrm{~m}$ thickness has been dumped. The experiences from the "Neuer Lugteich" revealed 5 that this clay layer is an optimal vertical barrier for seeping water also without any further compaction. Overlying of the clay is approximately $2-3 \mathrm{~m}$ of sandy Quaternary substrate which has been applied as the top layer. The mining specific acidification effect due to pyrite oxidation has been widely excluded at the "Chicken Creek" catchment by a careful selection of exclusively Quaternary sands for the storage layer. The 10 substrate of this artificial catchment stems from sandy accumulations of Pleistocene age and is free of pyrite and lignite. Generally, these substrates can be characterized as sands to loamy sands containing low amounts of carbonate. The surface has been levelled by caterpillars and tracks were removed by final flattening. The site has been left to an undirected and undisturbed development.

15 The "Chicken Creek" catchment has been constructed as a small hill with an altitude difference of approximately $15 \mathrm{~m}$ and an approximate inclination of $2 \%$. A hollow has been left at the deepest part of the site for the development of a small lake which allows for limnological investigations. Regarding the topography the catchment splits into two parallel parts which face together with a very little inclination (Fig. 4). Therefore, the initial surface runoff concentrates at the centre line forming the main course of the "Chicken Creek". Furthermore, small streams may develop in erosion gullies with temporary and probably permanent runoff. The "Chicken Creek" stream itself will develop downriver of the catchment area and will provide additional possibilities for investigations of initial stream development.

After construction works were finished in September 2005 and the area subsequently was fenced, Vattenfall Europe Mining AG as the owner of the site entrusted the area to the Brandenburg University of Technology at Cottbus for scientific purposes.

\section{HESSD}

6, 1769-1795, 2009

The artificial water catchment "Chicken Creek"

W. Gerwin et al.

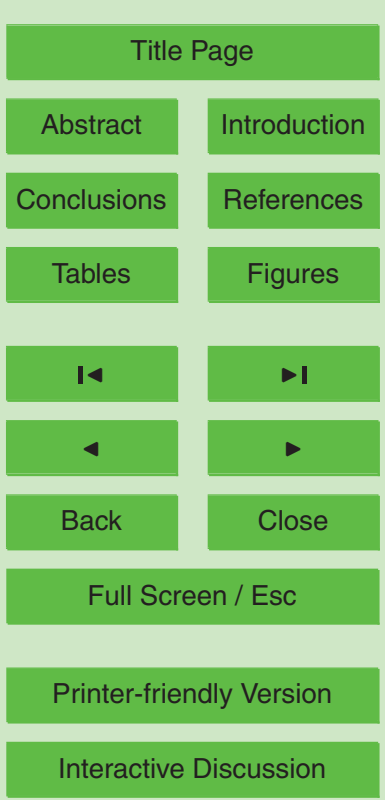


The SFB/TRR 38 investigates additional to the artificial watershed different reference sites. Reference sites are sites in initial development phases but under different environmental conditions. By means of such reference sites, characteristic processes and

5 structures of the initial development state found in the artificial catchment will be compared and validated. Site specific processes and structures can be distinguished from those which are characteristic for the initial states of ecosystems in general. In terms of chronosequences, reference sites can illustrate and help to understand the temporal process of developing ecosystems.

10 Inland dunes with ages from some decades, centuries to thousands of years and glacier forefields exposed for several years or up to several decades are examples of reference sites under investigation. A large number of inland dunes are located in the North-eastern German Lowland and also within the state of Brandenburg. Whereas the major part of these dunes were formed during the Late Pleistocene (between 13000

15 and $10000 \mathrm{BP}$ ) numerous dunes have been built up during periods of intense human land-use. Furthermore, recent sand dislocation processes are frequent on former military sites e.g. near Cottbus (Lieberose).

Another type of initial ecosystem is investigated in the Swiss Alps at the front end of the Damma glacier (Kanton Uri, municipality of Göschenen). The continuous retreat of this glacier provides the opportunity for chronosequence studies. Instrumented investigation sites exist for monitoring and process studies. The catchment in the forfield of the Damma glacier is also part of the CZEN network of Critical Zone observatories.

\section{First results of hydrological monitoring in the Chicken Creek catchment}

A central issue of the Collaborative Research Centre is the monitoring of the hydro25 logical behaviour during the development of the artificial catchment. With the end of the construction works ("point zero" of the ecosystem development) in autumn 2005

The artificial water catchment "Chicken Creek"

W. Gerwin et al.

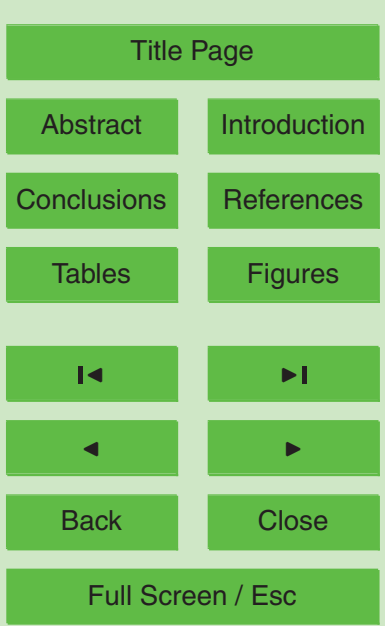

Printer-friendly Version

Interactive Discussion 
the first measuring devices were installed, in order to document the initial state of the system as well as to study the genesis of structures. Figure 5 shows the monitoring instrumentation installed, to date, at the site. First preliminary results on the hydrology of the artificial catchment "Chicken Creek" are presented here.

5 With regard to the level of the groundwater tables in the artificial catchment some obvious interdependencies with climatic parameters are already detectable. The cumulated climatic water balance compared with the development of the groundwater table is presented in Fig. 6 whereas the climatic water balance was determined as the difference between precipitation (corrected after Richter, 1995) and potential evapo10 transpiration (expressed as reference grassland evaporation after Allen et al., 1994). The climatic water balance was calculated for each hydrological year (1 November to 31 October) with zero as starting point, respectively, to allow for an overview of the weather dependent water supply. The water level in the automatically registering groundwater gauges N4, L4, 14, F4, and C4 shown in Fig. 6 are situated lengthwise in the middle of the catchment. The distances of these gauges from the artificial spring of the catchment are $40 \mathrm{~m}, 80 \mathrm{~m}, 140 \mathrm{~m}, 200 \mathrm{~m}$, and $260 \mathrm{~m}$, respectively. Groundwater tables reach their minima and maxima parallel to the cumulative climatic water balance. Hence, groundwater recharge is dominant in periods with low evapotranspiration (November to March). During periods of low or missing groundwater recharge (April to October) the groundwater table decreases according to the dominating groundwater discharge. Therefore, the temporal run of the groundwater table features a clear seasonal component with the only exception of gauge N4. This can be interpreted as a result of a punctual hydraulic discharge close to this gauge due to deep erosion gullies which have incised down to the groundwater table. The groundwater discharge 25 leads here to small naturally formed springs in these gullies. Interestingly, the groundwater tables generally still increase with time with regard to the complete observation period. Obviously, after a first period of almost three years the general trend of an increasing groundwater level has not been finished yet.

It is obvious that surface run-off triggered by rainfall represents an important part of

HESSD

6, 1769-1795, 2009

The artificial water catchment "Chicken Creek"

W. Gerwin et al.

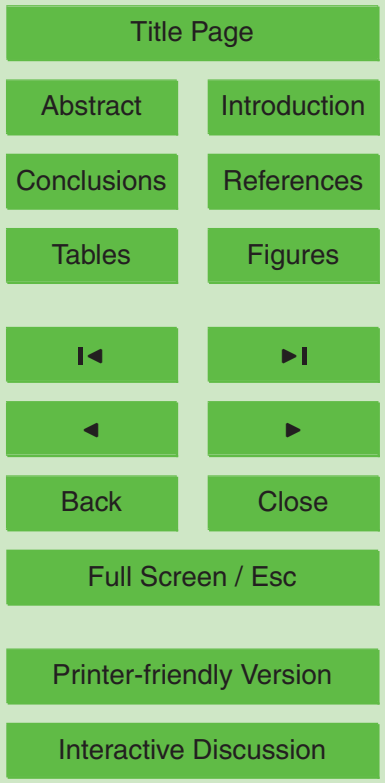

Interactive Discussion 
the water fluxes in the catchment at this stage of initial development. For example, on 16 December 2005 a rainfall event was monitored between 0 and 12 a.m. with a total precipitation of $15.3 \mathrm{~mm}$ and a volume of $920 \mathrm{~m}^{3}$ (calculated for a catchment area of $6 \mathrm{ha}$ ) (Fig. 7). The maximum intensity of the rainfall was $4.3 \mathrm{~mm} \mathrm{~h}^{-1}$. With increasing 5 intensity of rainfall first surface run-off has been registered at $5 \mathrm{a} . \mathrm{m}$. This resulted in an increase in the lake water level of $21 \mathrm{~cm}$. Accordingly, the total volume of the surface run-off can be calculated as $356 \mathrm{~m}^{3}$ by means of the water level-volume relationship of the lake (run-off coefficient 0.39).

Likewise, the lake level curve shows a clear relation between precipitation and in10 creasing water level (Fig. 8). The lake filled up for the first time immediately after snow melting in January 2006. Surface run-off was promoted by frozen soil at that time. The lake rose to a very high level during this event as the construction of the "Chicken Creek" streambed was not finished at that time and, therefore, the lake still had no clear discharge unit. After completion of the discharge unit in 2006 the water was not able to rise to this level again. However, the changes of the lake level are still strongly dependent on episodic surface run-off from the watershed after marked precipitation events. After the beginning of most rainfall events the water level rises quickly. Otherwise, the water level of the lake decreases in periods with low precipitation and high evaporation. Obviously, the influx into the lake from groundwater discharge is still much lower than losses due to evaporation.

The dominating surface run-off on the poorly vegetated site promoted erosion processes and resulted in a wide-stretched network of erosion gullies. In order to monitor and quantify the relation between precipitation and run-off, flumes were installed as flow rate indicators at two of the gullies. Figure 9 shows one of these flumes dur25 ing an exemplary run-off event with the registered flow rates. At the "Neuer Lugteich" catchment the development of water repellent soil surface structures (e.g. soil crusts) was observed during this initial phase of soil formation. Soil organic matter accumulation and stabilization have been found to play an important role (Biemelt et al., 2005; Fettweis et al., 2005; Buczko and Bens, 2006; Lemmnitz et al., 2008). As the result
HESSD

$6,1769-1795,2009$

The artificial water catchment "Chicken Creek"

W. Gerwin et al.

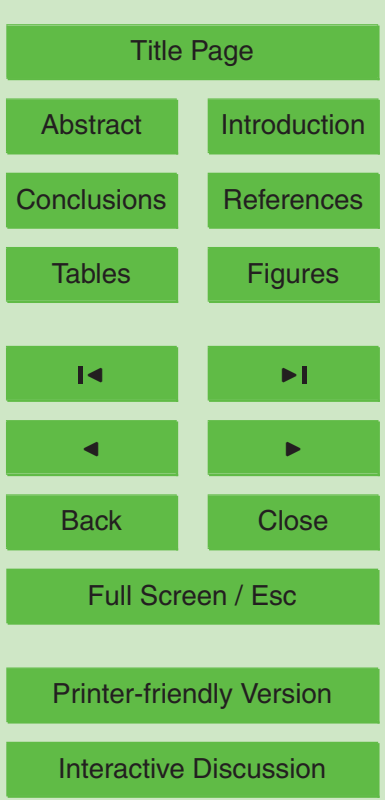


episodic surface runoff occurs and a network of erosion rills has formed despite of low annual precipitation, sandy surface materials and mainly slight slope gradients. Similar processes are expected to be effective at the "Chicken Creek" catchment.

\section{Conclusions}

5 The artificial catchment "Chicken Creek" represents a landscape unit which can be characterized by a relatively low complexity in the beginning and well documented initial structures and boundaries. Therefore, the catchment represents a unique opportunity to test, validate and optimize not only hydrological models and model components. A first modelling workshop was held in December 2008 in order to compare between 10 results of different hydrological model approaches and between modelling predictions and the real development of the catchment revealed by monitoring (cf. Holländer et al., 2009).

With regard to the Critical Zone concept the site seems to be an appropriate observatory for investigating and monitoring processes and developing structures during the 15 initial phase of an ecosystem. The concept of the Collaborative Research Centre which investigates the catchment's development has a broad interdisciplinary approach. According to the central hypotheses of the project physical and particularly hydrological processes and structures are of special interest in the beginning. It is hypothesised that the development of an ecosystem follows a sequence from a Geo-System to a Hydro20 Geo-System and finally to a Bio-Hydro-Geo-System. The latter can be interpreted as an equivalent synonym for "ecosystem". With regard to the first results of monitoring it can be concluded that the development of the Hydro-Geo-System is still going on as the recharge processes of the local groundwater body are still ongoing. One important issue of the Collaborative Research Centre will be to elucidate and distinguish different

For further information visit the project homepage under: http://www.tu-cottbus.de/ sfb_trr/.

HESSD

6, 1769-1795, 2009

The artificial water catchment "Chicken Creek"

W. Gerwin et al.

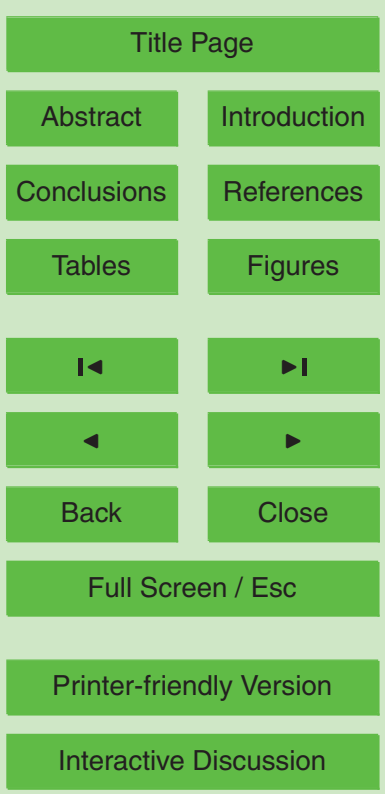

Interactive Discussion 
Acknowledgements. This study is part of the Transregional Collaborative Research Centre 38 (SFB/TRR 38) which is financially supported by the Deutsche Forschungsgemeinschaft (DFG, Bonn) and the Brandenburg Ministry of Science, Research and Culture (MWFK, Potsdam). The authors also thank Vattenfall Europe Mining AG for providing the research site.

HESSD

6, 1769-1795, 2009

The artificial water catchment "Chicken Creek"

Allen, R. G., Smith, M., Perrier, A., and Pereira, L.: An update for definition of reference evaporation, ICID Bulletin, 43(2), 1-34, 1994.

Anderson, S. P., Bales, R. C., and Duffy, C. J.: Critical zone observatories: building a network to advance interdisciplinary study of Earth surface processes, Mineral. Mag., 72, 7-10, doi:10.1180/minmag.2008.072.1.7, 2008.

Barbour, S. L., Chapman, D., Qualizza, C., Kessler, S., Boese, C., Shurniak, R., Meiers, G., O'Kane, M., Hendry, J., and Wall, S.: Tracking the evolution of reclaimed landscapes through the use of instrumented watersheds - a brief history of the Syncrude Southwest 30 Overburden Reclamation Research Program, Proc. Int. Instrumented Watershed Symp., Edmonton,

15 Canada, www.rr.ualberta.ca/oilsands/IIWS.htm, 2004

Biemelt, D., Schapp, A., Kleeberg, A., and Grünewald, U.: Overland flow, erosion, and related phosphorus and iron fluxes at plot scale: a case study from a non-vegetated lignite mining dump in Lusatia, Geoderma, 129, 4-18, doi:10.1016/j.geoderma.2004.12.030, 2005.

Buczko, U. and Bens, O.: Assessing soil hydrophobicity and its variability through the soil profile using two different methods, Soil Sci. Soc. Am. J., 70, 718-727, doi:10.2136/sssaj2005.0183, 2006.

Campbell, J. L., Driscoll, C. T., Eagar, C., Likens, G. E., Siccama, T. G., Johnson, C. E., Fahey, T. J., Hamburg, S. P., Holmes, R. T., Bailey, A. S., and Buso, D. C.: Long-term trends from ecosystem research at the Hubbard Brook Experimental Forest, Gen. Tech. Rep. NRS-17, Newtown Square, PA, US Dept. Agriculture, Forest Service, Northern Research Station, 2007.

Chorover, J., Kretzschmar, R., Garcia-Pichel, F., and Sparks, D. L.: Soil biogeochemical processes within the Critical Zone, Elements, 3, 321-326, 2007.

Ellenberg, H., Mayer, R., and Schauermann, J.: Ökosystemforschung; Ergebnisse des Sollingprojektes 1966-1986, Ulmer, Stuttgart, 1986.
W. Gerwin et al

Title Page

Abstract

Introduction

Conclusions

References

Tables

Figures

14

4

Back

Close

Full Screen / Esc

Printer-friendly Version

Interactive Discussion 
Elshorbagy, A. and Barbour, S. L.: Probabilistic approach for design and hydrologic performance assessment of reconstructed watersheds, J. Geotech. Geoenviron., 133, 1110-1118, doi:10.1061/(ASCE)1090-0241(2007)133:9(1110), 2007.

Elshorbagy, A., Jutla, A., Barbour, S. L., and Kells, J.: System approach to assess the 5 sustainability of reclamation of disturbed watersheds, Can. J. Civil Eng., 32, 144-158, doi:10.1139/L04-112, 2005.

Fettweis, U., Bens, O., and Hüttl, R. F.: Accumulation and properties of soil organic carbon at reclaimed sites in the Lusatian lignite mining district afforested with Pinus spec., Geoderma, 129, 81-91, doi:10.1016/j.geoderma.2004.12.034, 2005.

10 Fränzle, O., Kappen, L., Blume, H.-P., and Dierssen, K.: Ecosystem Organization of a Complex Landscape; Long-term Research in the Bornhöved Lake District, Germany, Ecological Studies, 202, Springer, Berlin, Heidelberg, 2008.

Gburek, W. J. and Folmar, G. J.: A ground water recharge field study: site characterization and initial results, Hydrol. Process., 13, 2813-2831, 1999.

Gu, W.-Z.: Field research on surface water and subsurface water relationships in an artificial experimental catchment, in: Interaction between Groundwater and Surface Water, edited by: Dahlblom, P. and Lindh, G., Proceedings of International Symposium Ystad, Sweden, 30 May-3 June 1988, 33-41, 1988.

Gu, W.-Z. and Freer, J.: Patterns of surface and subsurface runoff generation, IAHS Publication $20 \quad$ Series, 229, 265-273, 1995.

Gu, W.-Z., Liu, C.-M., Song, X.-F., Yu, J.-J., and Xia, J.: Hydrological experimental system and environmental isotope tracing: a review on the occasion of the 50th Anniversary of Chinese basin studies and the 20th Anniversary of Chuzhou Hydrology Laboratory, in: Xi, R.-Z., Gu, W.-Z., and Seiler, K.-P. (Eds.): Research Basins and Hydrological Planning, Proceedings of the International Conference on Research Basins and Hydrological Planning, 22-31 March, Hefei/Anhui, China, 11-18, London, 2004.

Haubrock, S., Chabrillat, S., and Kaufmann, H.: Application of hyperspectral imaging and laser scanning for the monitoring and assessment of soil erosion in a recultivation mining area, in: Erasmi, S., Cyffka, B., and Kappas, M. (Eds.): Remote Sensing and GIS for Environmental 30 Studies: Applications in Geography, Goltze, 230-237, 2004.

Haubrock, S., Chabrillat, S., Lemmnitz, C., and Kaufmann, H.: Surface soil moisture quantification models from reflectance data under field conditions, Int. J. Remote Sens., 29, 3-29, doi:10.1080/01431160701294695, 2008.
HESSD

6, 1769-1795, 2009

\section{The artificial water catchment "Chicken Creek"}

W. Gerwin et al.

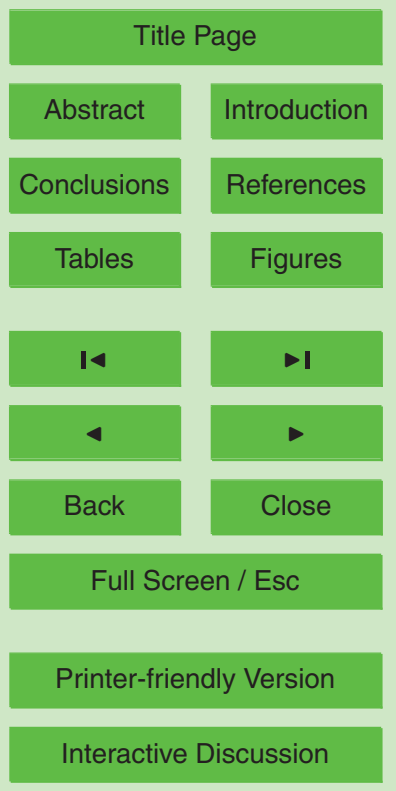


Holländer, H. M., Blume, T., Bormann, H., Buytaert, W., Chirico, G. B., Exbrayat, J.-F., Gustafsson, D., Hölzel, H., Kraft, P., Stamm, C., Stoll, S., Blöschl, G., and Flühler, H.: Comparative prediction of discharge from an artificial catchment (Chicken Creek) using a limited data base, Hydrol. Earth Syst. Sci. Discuss., in preparation, 2009.

5 Kendall, C., McDonnell, J. J., and Gu, W.-Z.: A look inside "black box" hydrograph separation models: a study at the Hydrohill catchment, Hydrol. Process., 15, 1877-1902, doi:10.1002/hyp.245, 2001.

Kendzia, G., Reißmann, R., and Neumann, T.: Targeted development of wetland habitats for nature conservation fed by natural inflow in the post-mining landscape of Lusatia, World Mining, 60, 88-95, 2008.

Kuhnert, M., Haubrock, S., Lemmnitz, C., Thoss, H., Bens, O., Chabrillat, S. and Güntner, A.: Quantification of near-surface processes in a microscale catchment combining pedological, hydrological and hyperspectral data, in: Tropeano, D., Arattano, M., Maraga, F., and Pelissero, C. (Eds.): Progress in Surface and Subsurface Water Studies at Plot and Small Basin Scale, Proceedings of the European Network of Experimental and Representative Basins, Euromediterranean Conference ERB2004, Consiglio Nazionale delle Ricerche - Italian National Research Council, Turin, 2005.

Lemmnitz, C., Kuhnert, M., Bens, O., Güntner, A., Merz, B., and Hüttl, R. F.: Spatial and temporal variations of soil water repellency and the influence on surface runoff, Hydrol. Process., $20 \quad 22,1976-1984$, doi:10.1002/hyp.6782, 2008.

Lemonds, P. J. and McGray, J. E.: Modeling hydrology in a small Rocky Mountain watershed serving large urban populations, J. Am. Water Resour. As., 43, 875-887, doi:10.1111/j.17521688.2007.00069.x, 2007.

Nicolau, J.-M.: Runoff generation and routing on artificial slopes in a Mediterraneancontinental environment: the Teruel coalfield, Spain, Hydrol. Process., 16, 631-647, doi:10.1002/hyp.308, 2002.

Richter, D.: Ergebnisse methodischer Untersuchungen zur Korrektur des systematischen Meßfehlers des Hellmann-Niederschlagsmessers, Berichte des Deutschen Wetterdienstes, 194, Offenbach, 1995.

so Schaaf, W., Gerwin, W., Kögel-Knabner, I., Munch, J.-C., Grünewald, U., and Hüttl, R. F.: Patterns and processes of initial ecosystem development in an artificial catchment, Suppl. Geochim. Cosmochim. Ac., 72, 12S, A827, doi:10.1016/j.gca.2008.05.021, 2008.

Sivapalan, M., Takeuchi, K, Franks, S. W., Gupta, V. K., Karambiri, H., Lakshmi, V., Liang, X.,

HESSD

6, 1769-1795, 2009

The artificial water catchment "Chicken Creek"

W. Gerwin et al.

Title Page

Abstract Introduction

Conclusions

Tables

References

Figures

14

- I

4

Back

Close

Full Screen / Esc

Printer-friendly Version

Interactive Discussion 
McDonnell, J. J., Mendiondo, E. M., O'Connell, P. E., Oki, T., Pomeroy, J. W., Schertzer, D., Uhlenbrook, S., and Zehe, E.: IAHS decade on Predictions in Ungauged Basins (PUB), 2003-2012: shaping an exciting future for the hydrological sciences, Hydrolog. Sci. J., 48, 857-880, 2003.

5 Waide, R., French, C., Sprott, P., and Williams, L.: The International Long Term Ecological Research Network 1998, US LTER Network, Department of Biology, University of New Mexico, 1998.

Walker, L. R. and del Moral, R.: Primary Succession and Ecosystem Rehabilitation, Cambridge, 2003.

10 Wilding, L. P. and Lin, H. S.: Advancing the frontiers of soil science towards a geoscience, Geoderma 131, 257-274, doi:10.1016/j.geoderma.2005.03.028, 2006.

\section{HESSD}

6, 1769-1795, 2009

The artificial water catchment "Chicken

Creek"

W. Gerwin et al.

Title Page

Abstract

Introduction

Conclusions

References

Tables

Figures

14

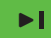

4

Back

Close

Full Screen / Esc

Printer-friendly Version

Interactive Discussion 
Table 1. Selected examples of artificial watersheds for scientific purposes and their characteristics.

\begin{tabular}{|c|c|c|c|c|}
\hline & Hydrohill & $\begin{array}{l}\text { South Bison } \\
\text { Hills }\end{array}$ & $\begin{array}{l}\text { El Moral } \\
\text { artificial slopes }\end{array}$ & $\begin{array}{l}\text { Chicken Creek } \\
\text { catchment }\end{array}$ \\
\hline country & China & Canada & Spain & Germany \\
\hline $\begin{array}{l}\text { main involved } \\
\text { disciplines }\end{array}$ & hydrology & $\begin{array}{l}\text { hydrology, soil } \\
\text { science }\end{array}$ & $\begin{array}{l}\text { hydrology, soil } \\
\text { science, } \\
\text { geomorphology }\end{array}$ & $\begin{array}{l}\text { hydrology, soil } \\
\text { science, } \\
\text { geomorphology, } \\
\text { biology, } \\
\text { limnology }\end{array}$ \\
\hline & disciplinary & & & interdisciplinary \\
\hline $\begin{array}{l}\text { study area } \\
\text { (location) }\end{array}$ & $\begin{array}{l}\text { natural hillside, } \\
\text { excavated and } \\
\text { reinforced }\end{array}$ & $\begin{array}{l}\text { Mildred Lake } \\
\text { mine (oil sand } \\
\text { mining area) }\end{array}$ & $\begin{array}{l}\text { El Moral mine } \\
\text { (coal open cast } \\
\text { mine) }\end{array}$ & $\begin{array}{l}\text { Welzow-Süd } \\
\text { (lignite open } \\
\text { cast mine) }\end{array}$ \\
\hline surface area & $490 \mathrm{~m}^{2}$ & $\begin{array}{l}\text { different sub } \\
\text { sites with } \\
10000 \mathrm{~m}^{2} \text { (test } \\
\text { sites for } \\
\text { overburden } \\
\text { storage) }\end{array}$ & $\begin{array}{l}\text { different } \\
\text { microcatchments } \\
\text { between } 60 \text { and } \\
114 \mathrm{~m}^{2}\end{array}$ & $60000 \mathrm{~m}^{2}$ \\
\hline $\begin{array}{l}\text { boundary } \\
\text { conditions }\end{array}$ & $\begin{array}{l}\text { artificially } \\
\text { defined, walls } \\
\text { made of } \\
\text { concrete }\end{array}$ & - & $\begin{array}{l}\text { natural } \\
\text { developed } \\
\text { microcatchments } \\
\text { in a post mining } \\
\text { landscape }\end{array}$ & $\begin{array}{l}\text { surface flattened } \\
\text { and shaped with } \\
\text { defined surface } \\
\text { and sub-surface } \\
\text { boundaries (clay } \\
\text { walls) }\end{array}$ \\
\hline aquiclude & concrete & - & - & $\begin{array}{l}\text { clay layer } \\
(>1-2 \mathrm{~m})\end{array}$ \\
\hline
\end{tabular}

HESSD

$6,1769-1795,2009$

\section{The artificial water catchment "Chicken Creek"}

W. Gerwin et al.

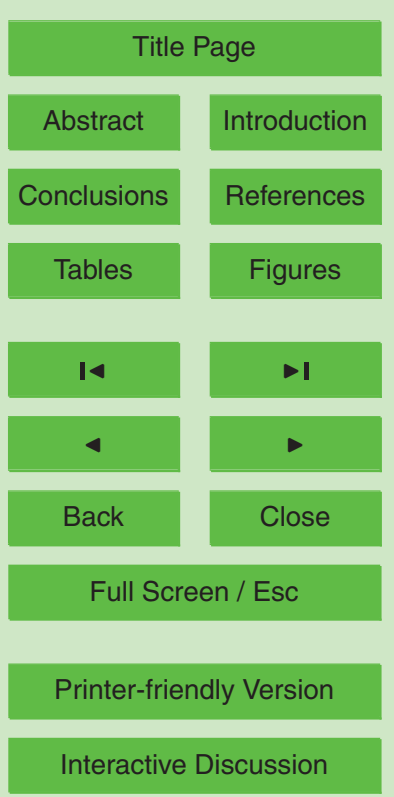




\section{HESSD}

Table 1. continued.

6, 1769-1795, 2009

\begin{tabular}{|c|c|c|c|c|}
\hline country & Hydrohill & $\begin{array}{l}\text { South Bison } \\
\text { Hills }\end{array}$ & $\begin{array}{l}\text { El Moral } \\
\text { artificial slopes }\end{array}$ & $\begin{array}{l}\text { Chicken Creek } \\
\text { catchment }\end{array}$ \\
\hline & & & & \\
\hline substrate & silty loam & $\begin{array}{l}\text { different types } \\
\text { of cover layers }\end{array}$ & $\begin{array}{l}\text { different types } \\
\text { of overburden } \\
\text { substrate }\end{array}$ & loamy sand \\
\hline $\begin{array}{l}\text { surface cover/ } \\
\text { vegetation }\end{array}$ & grassland & $\begin{array}{l}\text { different types } \\
\text { of re-vegetation }\end{array}$ & $\begin{array}{l}\text { reclamation, } \\
\text { re-vegetation } \\
\text { (grasses) }\end{array}$ & $\begin{array}{l}\text { bare soil } \\
\text { surface, left for } \\
\text { free succession }\end{array}$ \\
\hline $\begin{array}{l}\text { primary } \\
\text { purpose }\end{array}$ & $\begin{array}{l}\text { scientific } \\
\text { utilization }\end{array}$ & $\begin{array}{l}\text { investigation of } \\
\text { reclamation } \\
\text { measures }\end{array}$ & $\begin{array}{l}\text { scientific } \\
\text { utilization }\end{array}$ & $\begin{array}{l}\text { scientific } \\
\text { utilization }\end{array}$ \\
\hline $\begin{array}{l}\text { research } \\
\text { activities }\end{array}$ & $\begin{array}{l}\text { studying } \\
\text { rainfall-runoff } \\
\text { processes }\end{array}$ & $\begin{array}{l}\text { applied research } \\
\text { e.g. studying } \\
\text { water storage in } \\
\text { different cover } \\
\text { layers }\end{array}$ & $\begin{array}{l}\text { studying runoff } \\
\text { generating, } \\
\text { routing and } \\
\text { erosion }\end{array}$ & $\begin{array}{l}\text { collaborative } \\
\text { investigation of } \\
\text { the initial } \\
\text { development of } \\
\text { an ecosystem }\end{array}$ \\
\hline references & $\begin{array}{l}\text { Gu et al. (2004), } \\
\text { Kendall et } \\
\text { al. (2001) }\end{array}$ & $\begin{array}{l}\text { Elshorbagy } \\
\text { et al. (2005), } \\
\text { Elshorbagy } \\
\text { and Barbour } \\
\text { (2007), Barbour } \\
\text { et al. (2004) }\end{array}$ & Nicolau (2002) & $\begin{array}{l}\text { Schaaf et } \\
\text { al. (2008) }\end{array}$ \\
\hline
\end{tabular}

The artificial water catchment "Chicken Creek"

W. Gerwin et al.

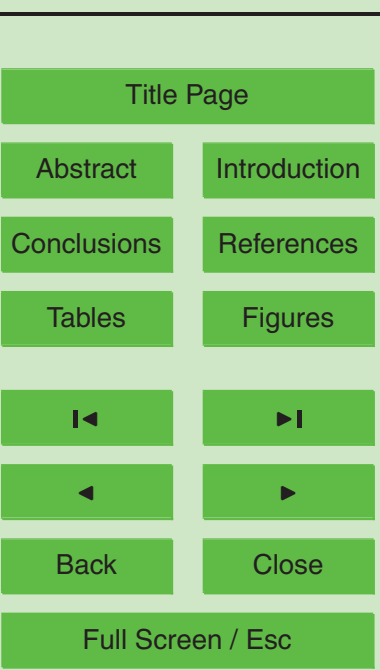

Printer-friendly Version

Interactive Discussion 


\section{HESSD}

6, 1769-1795, 2009

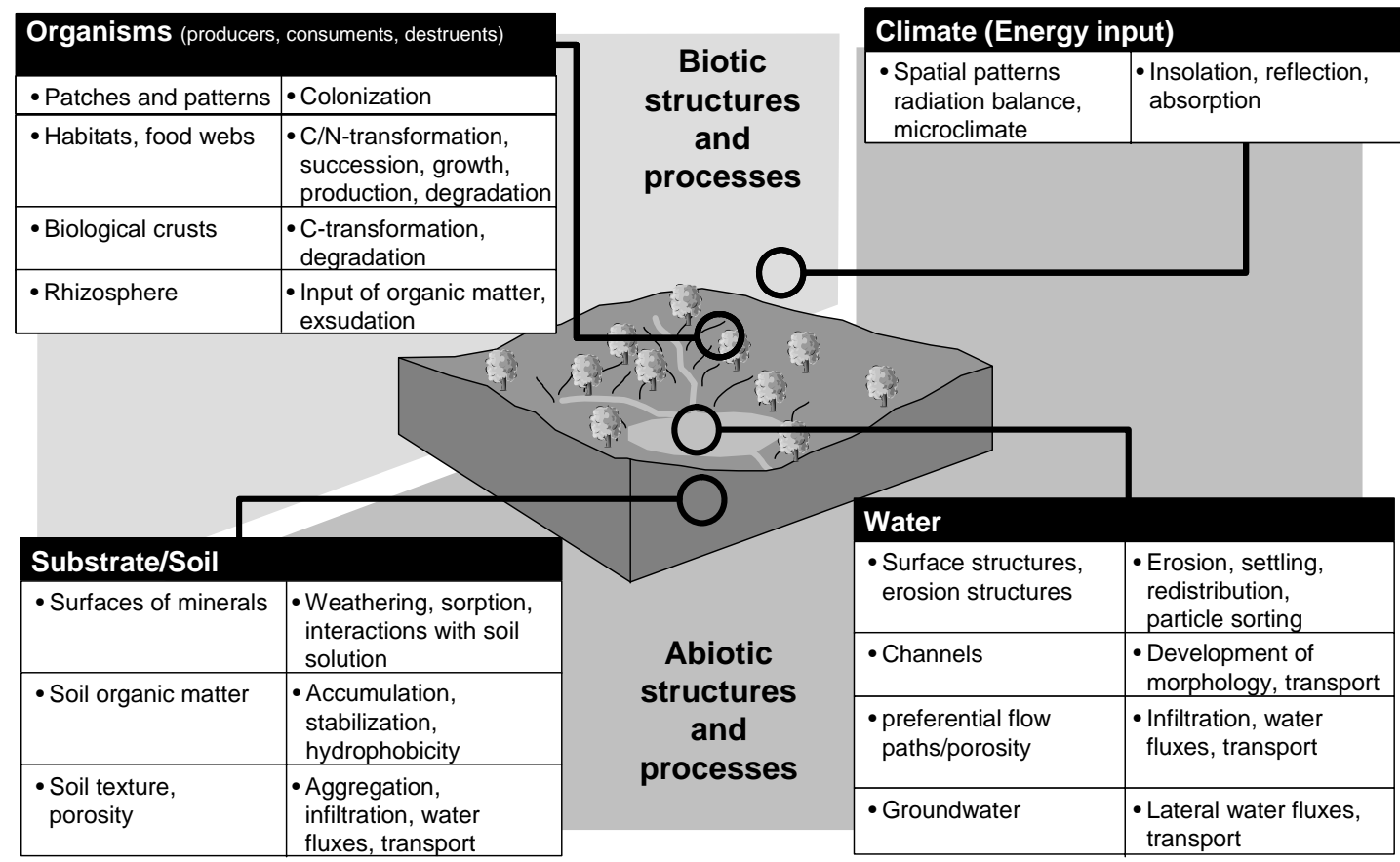

The artificial water catchment "Chicken Creek"

W. Gerwin et al.

\section{Title Page}

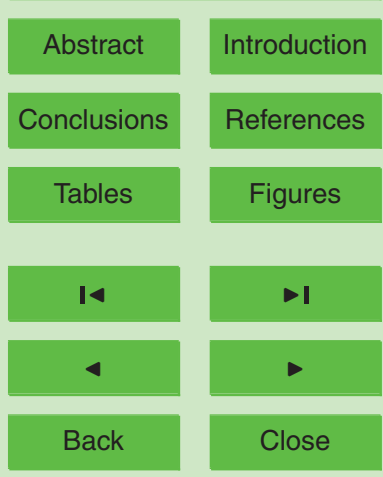

Full Screen / Esc

Fig. 1. Structures and processes of initial ecosystem development.

Printer-friendly Version

Interactive Discussion 


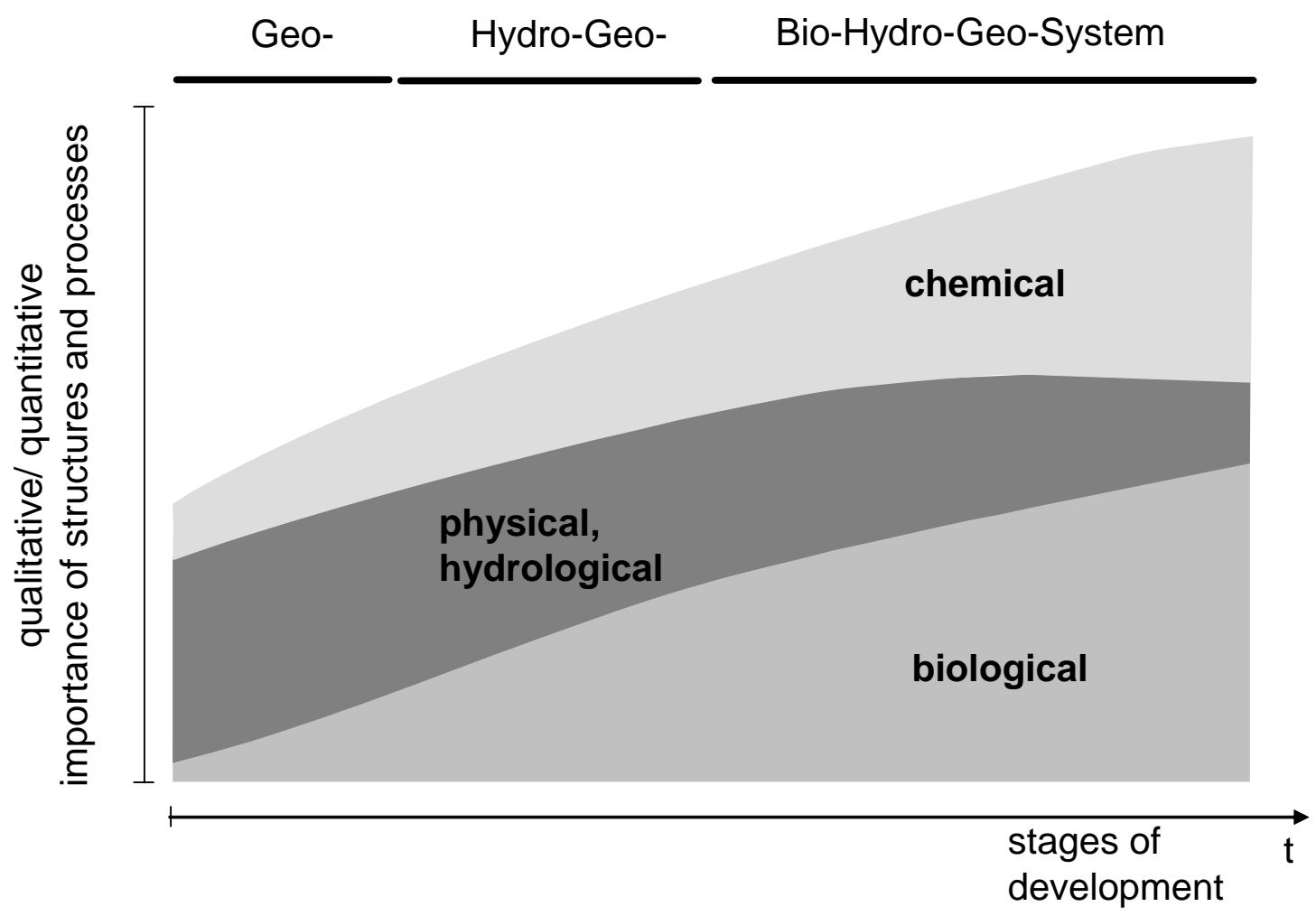

\section{$6,1769-1795,2009$}

The artificial water catchment "Chicken Creek"

W. Gerwin et al.

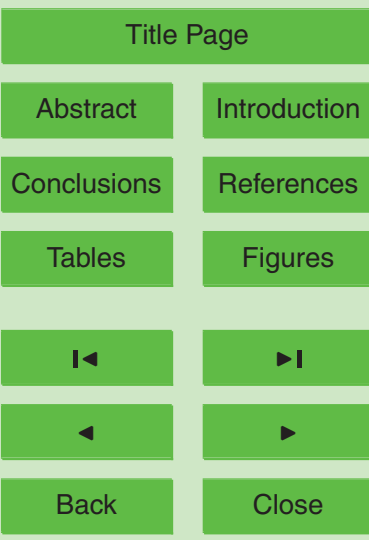

Full Screen / Esc

Fig. 2. Phases of the initial ecosystem development. 


\section{HESSD}

6, 1769-1795, 2009

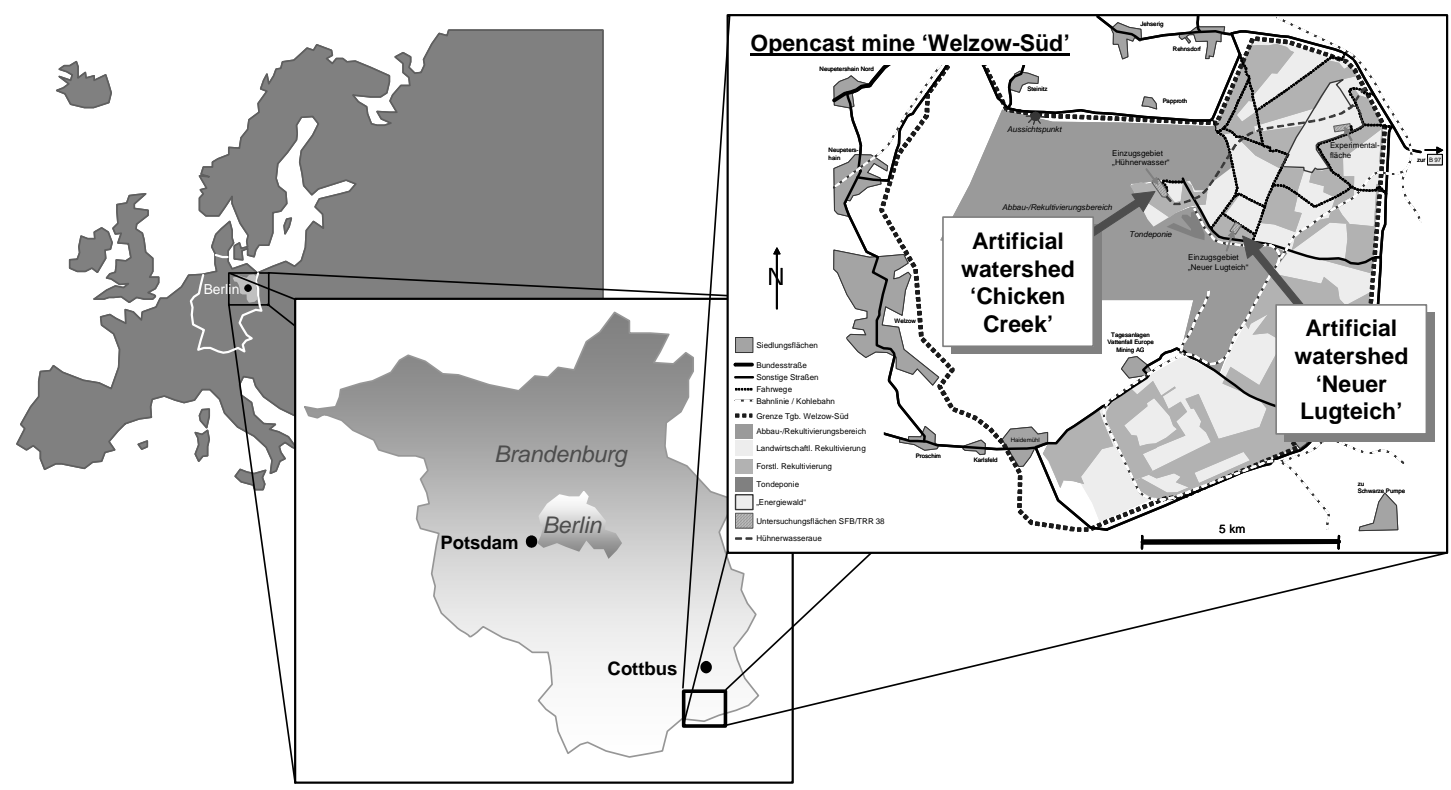

The artificial water catchment "Chicken Creek"

W. Gerwin et al.

Title Page

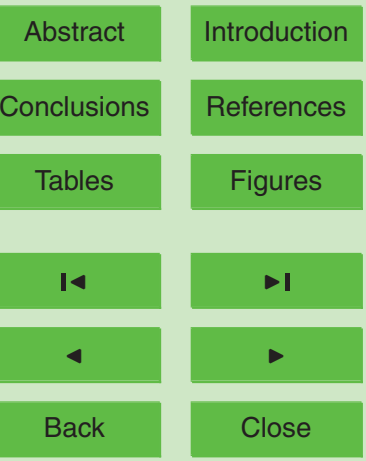

Full Screen / Esc

Fig. 3. Location of the two artificial catchments in the open cast mine Welzow-Süd.

Printer-friendly Version

Interactive Discussion 


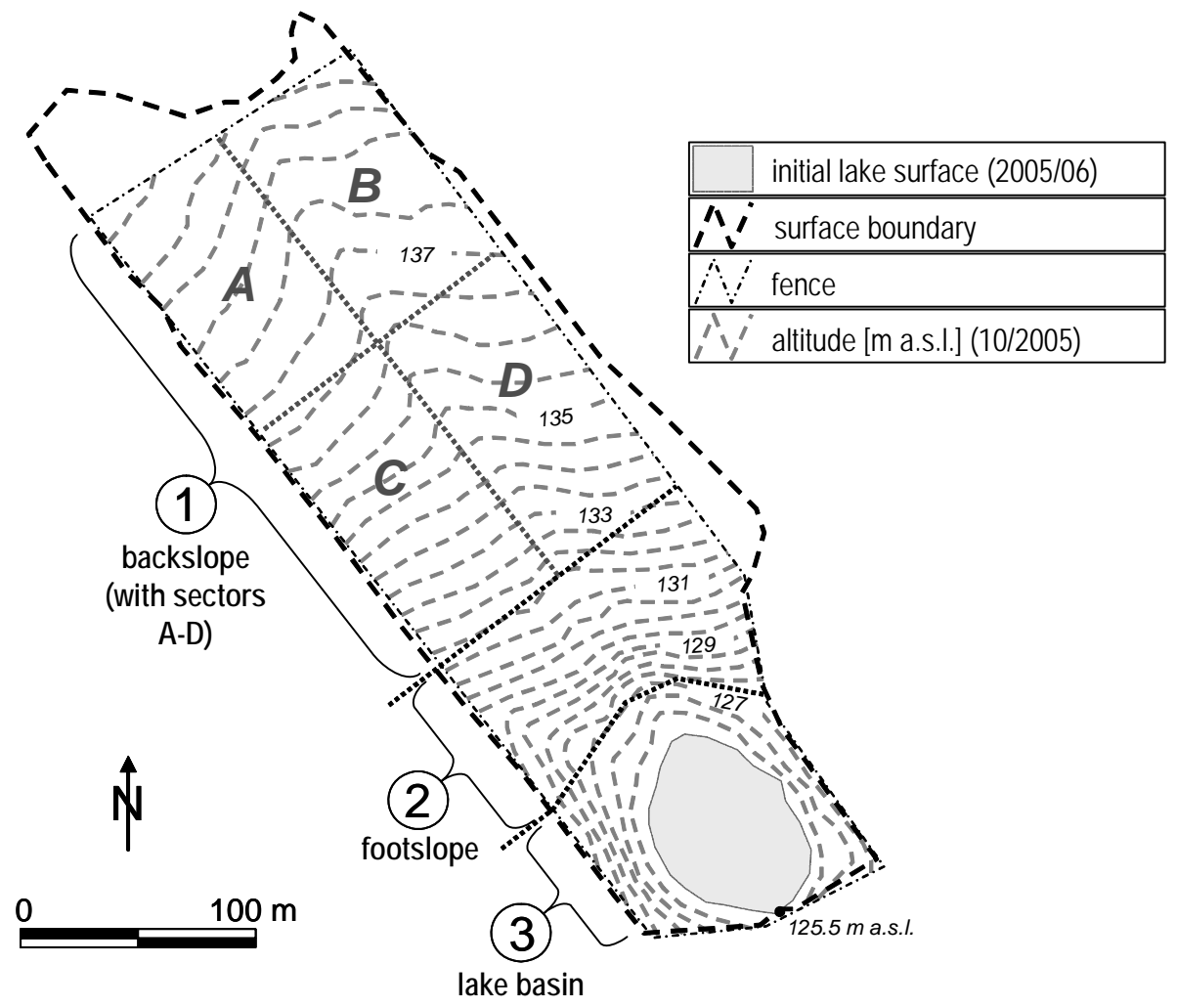

\section{6, 1769-1795, 2009}

\section{The artificial water catchment "Chicken Creek"}

W. Gerwin et al.

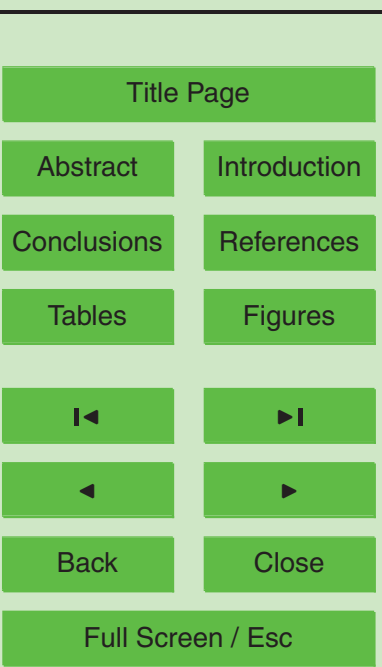

Fig. 4. Artificial catchment "Chicken Creek" with initial topography and sectors. 


\section{HESSD}

6, 1769-1795, 2009

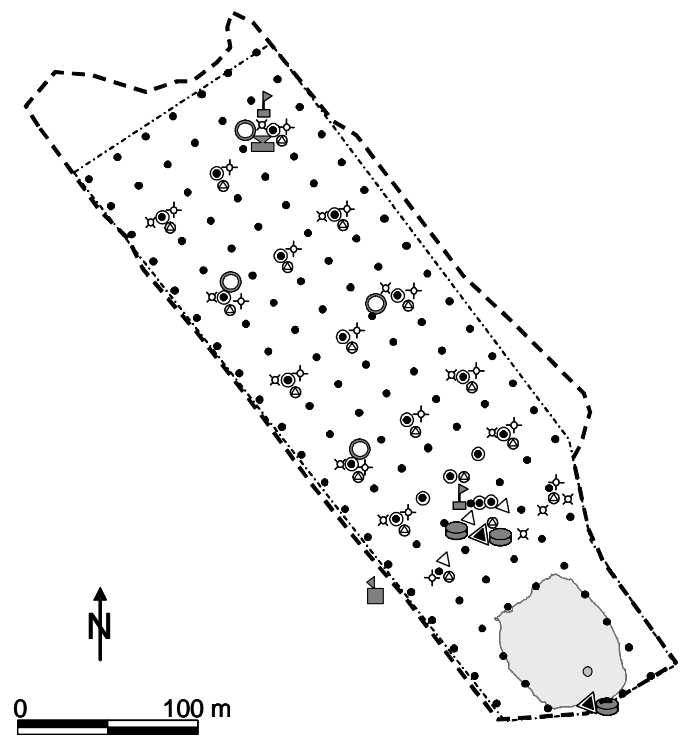

\begin{tabular}{|c|c|}
\hline • & $20 \times 20 \mathrm{~m}$ grid point \\
\hline & input data \\
\hline 占 & weather station \\
\hline$\Xi$ & dry/wet deposition sampler \\
\hline$\otimes$ & bulk immission sampler \\
\hline & hydrology \\
\hline ○ & groundwater gauges \\
\hline$\triangleleft$ & flow rate indicators (flumes) \\
\hline$\Delta$ & weirs I + II \\
\hline$\circ$ & water gauge lake \\
\hline & soil moisture \\
\hline$\phi$ & Soil moisture probes (PR2 profile) \\
\hline$x$ & tensiometers \\
\hline 4 & L-band radiometer (ELBARA) \\
\hline & soil/water solution \\
\hline 0 & soil pits (ceramic suction plates, TDR) \\
\hline$\theta$ & automatic water samplers \\
\hline
\end{tabular}

\section{The artificial water catchment "Chicken Creek"}

W. Gerwin et al.

Title Page

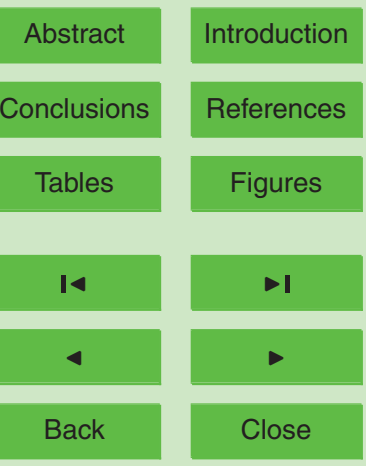

Full Screen / Esc

Printer-friendly Version

Interactive Discussion 


\section{HESSD}

$6,1769-1795,2009$
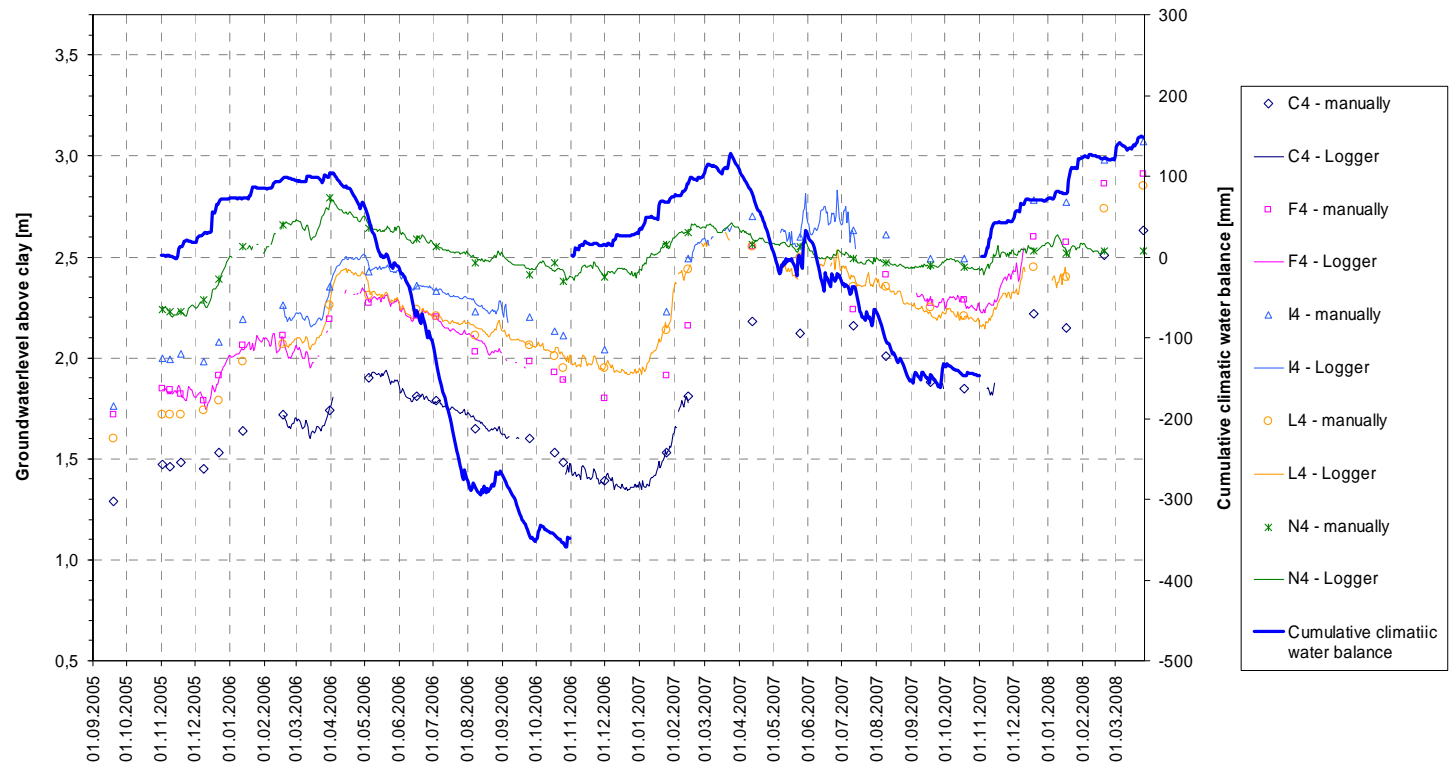

Fig. 6. Cumulative climatic water balance and development of groundwater levels.

\section{The artificial water catchment "Chicken Creek" \\ W. Gerwin et al.}

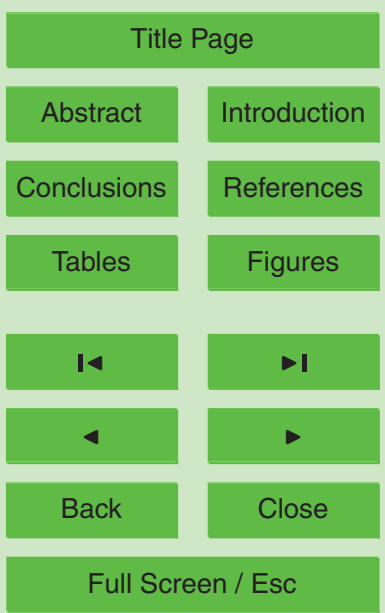

Printer-friendly Version

Interactive Discussion 


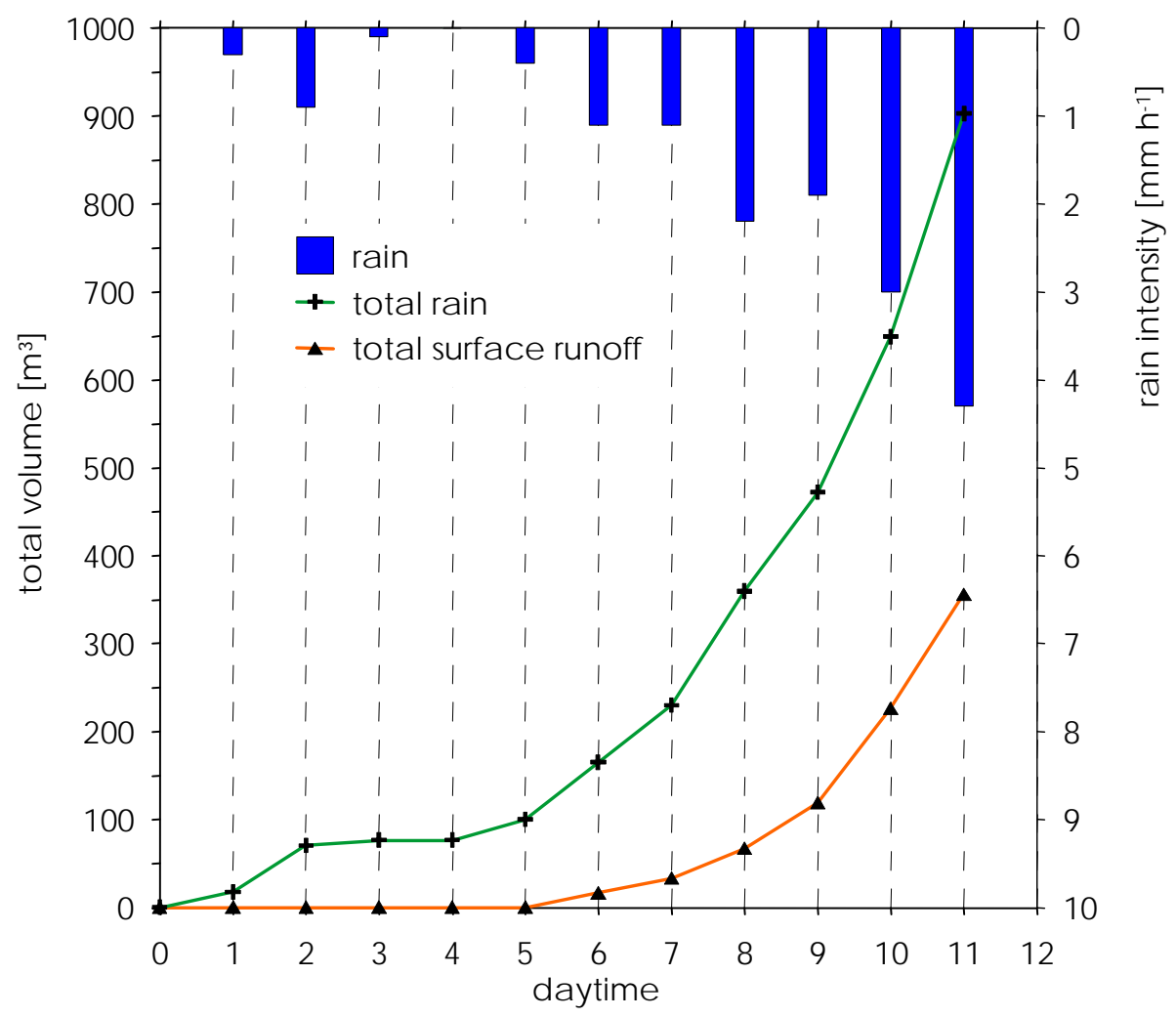

\section{6, 1769-1795, 2009}

The artificial water catchment "Chicken Creek"

W. Gerwin et al.

Title Page

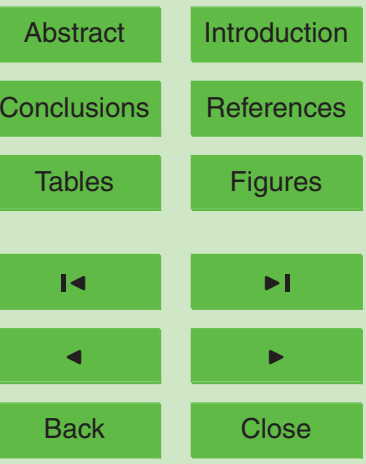

Full Screen / Esc

Printer-friendly Version

Fig. 7. Comparison of precipitation and runoff for 16 December 2005.

Interactive Discussion 
HESSD

6, 1769-1795, 2009

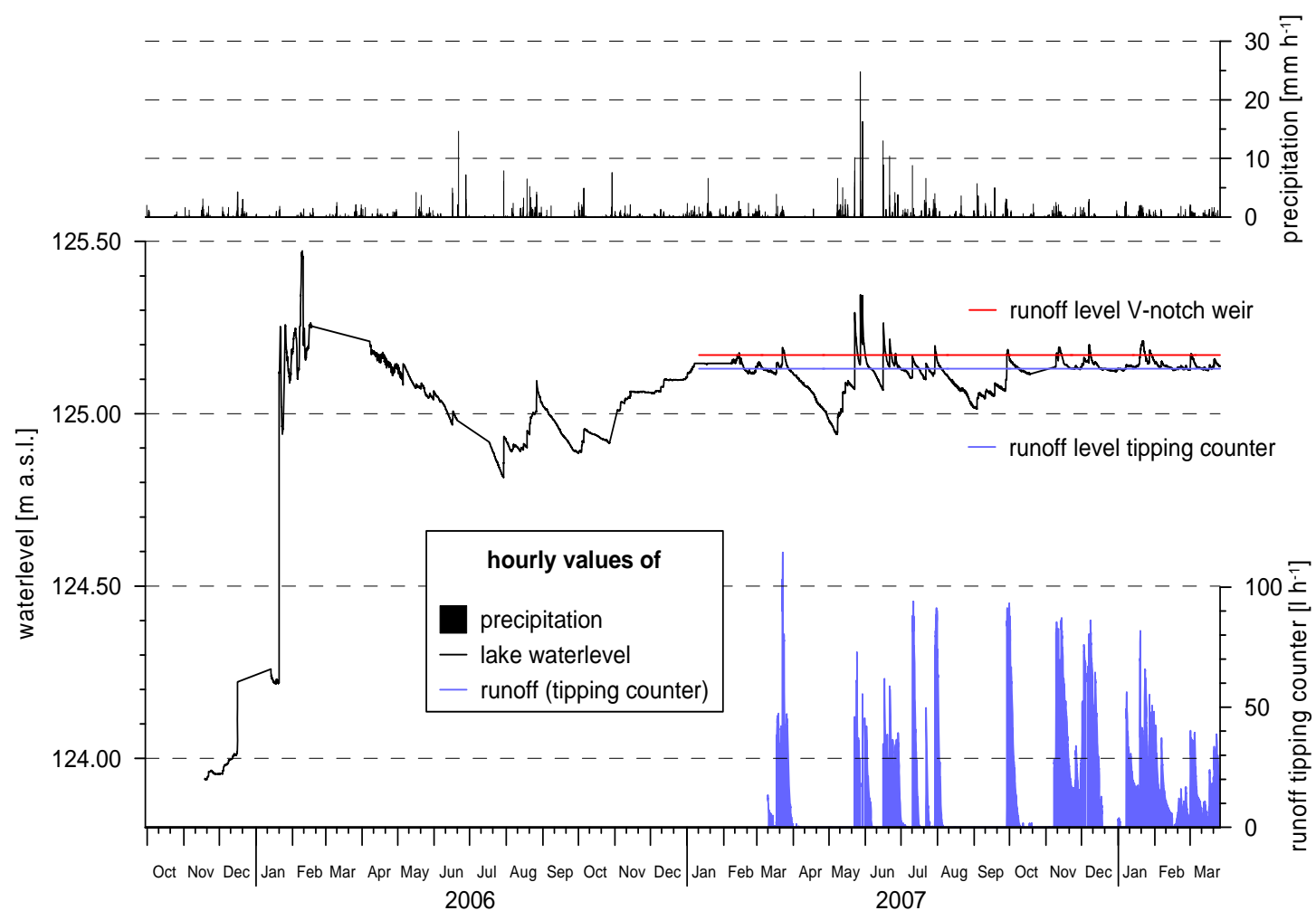

Fig. 8. Development of lake water level since formation of the catchment.

\section{The artificial water catchment "Chicken Creek"}

W. Gerwin et al.

Title Page

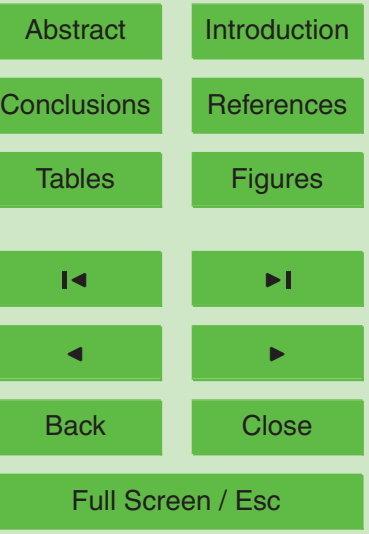

Printer-friendly Version

Interactive Discussion 


\section{HESSD}

6, 1769-1795, 2009
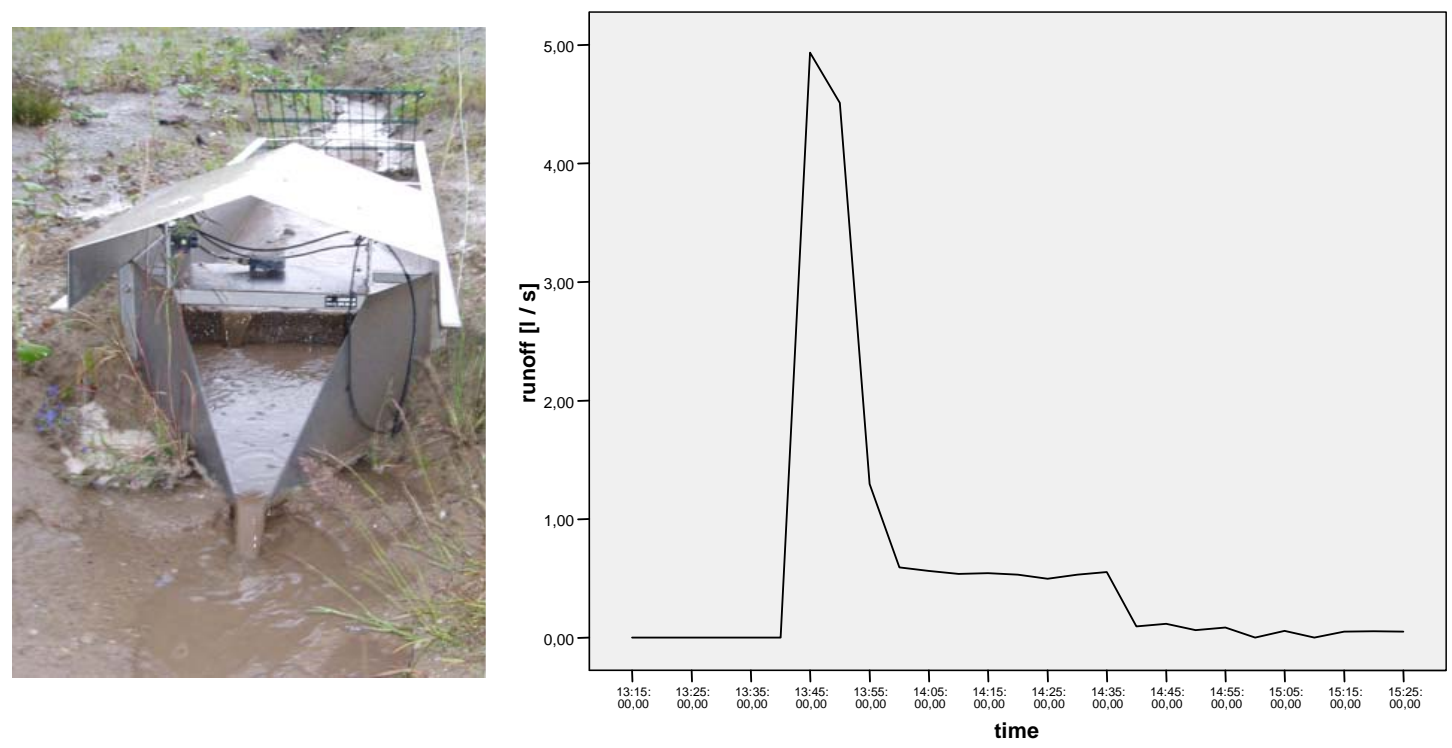

\section{The artificial water catchment "Chicken Creek"}

W. Gerwin et al.

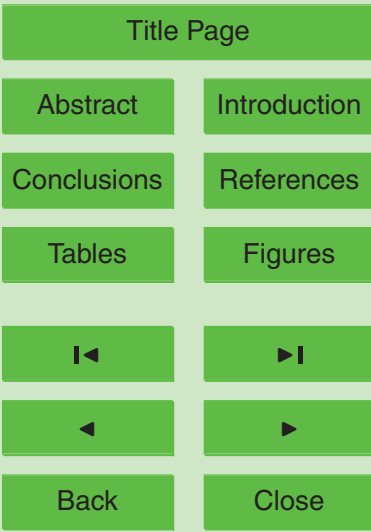

Fig. 9. Flume and registration of surface runoff during a rainstorm (maximum rain intensity $8.5 \mathrm{~mm} / 10 \mathrm{~min}$; 25 June 2008).

\section{Full Screen / Esc}

Printer-friendly Version

Interactive Discussion 